\title{
„VNÍMÁNÍ JE JIŽ VYJADŘOVÁNÍ““ Merleau-Pontyho první přednášky na Collège de France
}

\author{
Jan Halák
}

\section{Merleau-Pontyho filosofický projekt po roce 1945: proměna a překročení vnímání}

V roce 1953 Merleau-Ponty nastupuje na Collège de France, což mu po osmi letech ne příliš stabilního akademického působení přináší kvalitní badatelské zázemí a mimořádnou svobodu při volbě dalšího filosofického směřování. Způsob, jímž Merleau-Ponty tuto př́znivou situaci využívá, stojí sám o sobě za povšimnutí: zatímco několik předchozích let se věnoval přednáškám $\mathrm{z}$ dějin filosofie a výuce dětské psychologie a pedagogiky, své působení na Collège začíná revizí své disertační práce z r. 1945, kterou se pokouší prohloubit. ${ }^{1}$

Své první práce, díky nimž se stal „fenomenologem vnímáni““, nyní chápe nejen jako určitý výdobytek, ale také jako otevření obecnějšího filosofického problému. ${ }^{2}$ Originální modalita zkušenosti, kterou jsme odhalili při popisu vnímání jako náš „,prvotní kontakt s bytím“, není pouhým souborem „empirických zajímavostí“3 týkajících se jen vnímání, nýbrž nám „předepisuje itinerář a metodu“ pro další zkoumání, ${ }^{4}$ jež budou mít dokonce ontologické důsledky. Vnímající lidský subjekt se nespokojuje s tím, co je mu ve vnímání dáno, nýbrž se k tomu zpětně obrací a pokouší se to fixovat, shrnout, učinit disponibilním. Jinak řečeno,

1 M. Merleau-Ponty, Phénoménologie de la perception, Paris 1945; česky: $\mathrm{Fe}$ nomenologie vnímání, přel. J. Čapek, Praha 2013.

2 Srv. dva texty ke kandidatuře na Collège de France z přelomu let 1951 a 1952: M. Merleau-Ponty, Titres et travaux - Projet d'enseignement, in: týž, Parcours deux, Paris 2000, str. 9-35; týž, Un inédit de Maurice Merleau-Ponty, in: tamt., str. 36-48.

3 M. Merleau-Ponty, Fenomenologie vnímání, str. 277. Merleau-Ponty se v několika dalších textech ohrazuje proti námitkám, podle nichž by jeho fenomenologie vnímání byla jen popisem ,psychologických kuriozit“.

4 M. Merleau-Ponty, Titres et travaux-Projet d'enseignement, str. 22. 
usiluje o to překročit svou situaci, dospět k pravdě jako takové, jedním slovem myslet. Metodu Fenomenologie vnímání proto „musíme aplikovat v širším kontextu“, píše Merleau-Ponty, a na základě toho vypracovat „konkrétní teorii ducha“. 5

Zcela zásadní je, jak Merleau-Ponty dále vysvětluje, že v prvních pracích ,jsme na základě metodické abstrakce předstírali“, že se nacházíme ve světě bez řeči. ${ }^{6}$ Důležitým úkolem dalších zkoumání proto je studovat a popisovat konkrétní kulturní materiály, zejména řečové nástroje, díky nimž si mluvící subjekt osvojuje universálně platné, „veřejné“ významy. Musíme odhalit, jak za pomoci ,,rečového užití těla“, ${ }^{7}$ tj. stále ještě pomocí naší tělesnosti, překračujeme hranice naší vlastní perspektivy a našeho „přírodního“ postavení. Myšlení a komunikace, již myšlení předpokládá, jsou tak podle Merleau-Pontyho vůči vnímání „originálními útvary“, avšak zároveň pouze „přebírají“ (reprennent) vnímání, „zachovávají a překračují", tj. „sublimují" naši tělesnou existenci, spíše než že by ji rušily či se $\mathrm{k}$ ní připojovaly jako autonomní řád. ${ }^{8}$

Původ a zrod procesu „sublimace“ neboli fundace a překročení, jejž chce Merleau-Ponty sledovat na ose mezi vnímáním, vyjadřováním, řečí a myšlením, je podle něj nutno hledat v aktivním, „mimickém užití těla“ - v gestu. ${ }^{9}$ Právě gesto je sice stále ještě vnímatelný fenomén, ale již se obrací zpět ke vnímanému, aby v něm ukázalo něco z jeho smyslu, co ve vnímání orientovaném k předmětům bylo sice obsaženo, ale zůstávalo pouze implicitní. Gesto do perceptivního světa přináší „nadbytek smyslu“", ${ }^{10}$ protože činí tématem něco, co by bez něj zůstávalo pouze na pozadí vnímaných témat. Jakožto vyjadřovací akt nás gesto tedy ještě zcela neodpoutává od naší tělesně-perceptivní situace, ale začiná ji reorganizovat, provádí $\mathrm{v}$ ní operace, které ji proměňují, a tím podle Merleau-Pontyho začíná tradici, ve které tuto situaci nakonec překročí-

5 M. Merleau-Ponty, Un inédit de Maurice Merleau-Ponty, str. 43.

6 M. Merleau-Ponty, Titres et travaux - Projet d'enseignement, str. 22. Merleau-Ponty se otázce řeči věnuje i v jiném textu napsaném ve stejné době jako citované podklady ke kandidatuře: Sur la phénoménologie du langage, in: Signes, Paris 1960, str. 105-122.

7 M. Merleau-Ponty, Titres et travaux - Projet d'enseignement, str. 24.

8 M. Merleau-Ponty, Un inédit de Maurice Merleau-Ponty, str. 37 a 42; srv. týž, La prose du monde, Paris 1969, str. 173. Myšlenku „sublimace“ v tomto smyslu nacházíme již ve Fenomenologii vnímání, např. str. 168.

9 M. Merleau-Ponty, Un inédit de Maurice Merleau-Ponty, str. 43. Srv. již Fenomenologii vnímání, str. 223-252, kap. „Tělo jako výraz a fenomén mluvy“.

10 M. Merleau-Ponty, La prose du monde, str. 92. Viz níže, sekce 4. 
me v řeči a myšlení. ${ }^{11}$ Řeč je podle Merleau-Pontyho „pokračováním“ před-řečových forem vyjadřování (a každá promluva přinášející doposud nedisponibilní význam má gestický charakter), avšak zároveň tyto formy „proměňuje“. 12

Podle Merleau-Pontyho tedy gesto mírí na něco z vnímaného světa, o čem bude řeč mluvit nebo co bude např. matematika vyjadřovat algoritmem, tj. na něco, co bude myšlení nakonec myslet. Myšlenka „těla jakožto přirozeného symbolismu“, kterou Merleau-Ponty představuje již ve Fenomenologii vnímání, však ,není posledním slovem, nýbrž naopak ohlašuje pokračování“. 13 Ve svém prvním přednáškovém cyklu na Collège de France, „Smyslový svět a svět vyjadřování“, Merleau-Ponty provádí první kroky, jež by měly vést k vyjasnění takto načrtnuté struktury „překročeni“" vnímání a „přirozeného symbolismu“ těla ve vyjadřovacích aktivitách. Paradoxně si to vynutí retraktovat výsledky samotné fenomenologie vnímání a pokusit se je očistit od zbytků ontologických předsudků spojených s kartesiánskou tradicí. Přesněji, bude nutno zásadně revidovat naše pojetí vnímajícího subjektu a vnímaného, nakolik se vzájemně podmiňují a nakolik je toto podmiňování podrobeno různým druhům dynamiky. Cílem následujícího textu je představit a komentovat tyto dvě hlavní myšlenky v kontextu Merleau-Pontyho kursu, resp. vyjasnit to, co z nich lze rekonstruovat na základě vydání Merleau-Pontyho př́pravných poznámek $\mathrm{k}$ přednáškám. ${ }^{14}$

\section{Nová analýza vnímání bez pojmu vědomí}

Naznačili jsme, že Merleau-Ponty je přesvědčen, že jeho interpretace vnímání má ontologické důsledky a že umožňuje, ba dokonce vyžaduje

11 Srv. M. Merleau-Ponty, Un inédit de Maurice Merleau-Ponty, str. 42: Přechod mezi vnímáním a poznáním spočívá v tom, že „tělo má dvojí funkci. Svými ,smyslovými poli‘, celou svou organizací, je jakoby předurčeno k tomu, aby se přetvářelo podle prrirozených aspektů světa. Ale jakožto aktivní, schopné gest, výrazů a nakonec i řeči se obrací zpět ke světu, aby jej označilo“.

12 M. Merleau-Ponty, Titres et travaux-Projet d'enseignement, str. 27.

13 M. Merleau-Ponty, Résumés de cours, Paris 1968, str. 179-180. Srv. výše, pozn. 10 .

14 Znění přednášek samých se nedochovalo, $\mathrm{k}$ dispozici máme pouze Merleau-Pontyho prrípravné poznámky k přednáškám a jejich stručné shrnutí: M. Merleau-Ponty, Le monde sensible et le monde de l'expression. Cours au Collège de France. Notes, 1953, Genève 2011; týž, Résumés de cours, str. 11-21. 
vypracování „nové analýzy rozumu“. ${ }^{15} \mathrm{~V}$ roce 1953 má však ještě pocit, že se mu relevanci analýzy vnímání v tomto ohledu nepodařilo uspokojivě ukázat. Soudí tak již z ne prríliš chápavých reakcí filosofických autorit své doby, jak je lze sledovat zejména $\mathrm{v}$ diskusi k přednášce $\mathrm{z}$ roku 1946, která vyšla pod titulem Primát vnimání a jeho filosofické di̊sledky. ${ }^{16}$ Mnohem závažnější jsou ovšem Merleau-Pontyho vlastní kritické postřehy vůči způsobu, jakým dřive analýzu vedl: nyní se již domnívá, že ve Fenomenologii vnímání používal předmětu zkoumání neodpovídající tradiční pojmový aparát (45-46), ${ }^{17}$ což mělo vést $\mathrm{k}$ tomu, že analýzy „byly často negativní“ (46) a „nedostatečně vypracované“ (47). Zásadní obtíž v tomto bodě působí zejména pojem vědomí. V titulu přednášky uvedený pojem vyjadřování má nyní Merleau-Pontymu pomoci již provedené analýzy vnímání „,nově vyložit“, ,prohloubit“ $(51,45)$, a tak „opustit“, „Zpochybnit“, „nahradit“" právě pojem vědomí $(51,58,53)$.

Představa vědomí v kartesiánsko-kantovské tradici definuje vztah subjektu k předmětu způsobem, který se podle Merleau-Pontyho zásadně liší od tělesně-perceptivní existence ve světě. Vědomí má co činit pouze s významy (48), a to jakožto s něčím, co existuje „o sobě“ a samostatně (50). Jakožto vědomí proto dosahuji věci bez jakékoli distance, jsou pro mne bud' „zcela jasnými“ významy (49), nebo je nemohu mít. Tím jsem však od nich zároveň nekonečně vzdálen, protože věci mohou s vědomím „mít kontakt“, pouze nakolik je ono samo konstituuje, „nemohou se obrátit proti němu“ (48), nemohou je „zachytit“ a vtáhnout mezi sebe (55). ${ }^{18}$ Pojem vědomí podle Merleau-Pontyho současně implikuje pojetí smyslu jako podstaty: Smysl se stává odpovědí na otázku „Co je mi dáno?“, definicí: „každé vědomí je uchopením takovéto podstaty či její aplikací na nějaký jednotlivý př́ípad“ (48). V tomto smyslu je také

15 M. Merleau-Ponty, Résumés de cours, str. 11.

16 M. Merleau-Ponty, Primát vnímáni a jeho filosofické důsledky, přel. J. Halák, Praha 2011; srv. zejména reakce É. Bréhiera, J. Hyppolita a J. Beaufreta; srv. také M. Merleau-Ponty, Le monde sensible et le monde de l'expression, str. 46; a týž, Résumés de cours, str. 11. Tato kritika má pro Merleau-Pontyho zásadní význam a bude se k ní vracet i později, srv. E. de Saint-Aubert, Vers une ontologie indirecte, Paris 2006, str. 21-35.

17 Všechna čísla stran, jež uvádím př́ímo v textu, odkazují na vydání Merleau-Pontyho přípravných poznámek k přednáškám: M. Merleau-Ponty, Le monde sensible et le monde de l'expression.

18 Tento motiv Merleau-Ponty později prohloubí v přednáškách o pasivitě, srv. M. Merleau-Ponty, L'institution - La passivité. Notes de cours au Collège de France (1954-1955), Paris 2003, str. 157 nn. 
vědomí nachystáno k tomu, aby se stalo řečí, tzn. ,je již kladením určité výpovědi, mluvicím vědomím“ (49).

V protikladu k tomu je nutno konstatovat, že jakožto vnímající jsem vnímaným věcem blíže než vědomí, protože věc „,se zmocňuje mého těla, aby se od něj nechala vnímat (barva mi ukládá určitý životní rytmus...)“ (49). Jsoucna „přesahují“ do vnímajícího, „obkličuji““ (55) a „pronásleduji““ jej (56), zachycují jej do svých struktur. Zároveň si však věc výrazněji zachovává svou dálku, jelikož se ukazuje pouze prostřednictvím toho, co ve mně vyvolává, aniž by tím proto ještě opouštěla své místo: Věc vždy překračuje onu vibraci, kterou vyvolává v mém těle (56), zůstává „nepř́istupná“, je horizontem (181). Má-li vědomí své předměty jedině jako něco určeného, jakožto prrípad nějaké podstaty, na rovině perceptivního vztahu je i ta sebeurčenější danost figurou, která předpokládá nikoli tematicky daný horizont, tj. „něco neartikulovaného a pouze skrytě předpokládaného“ (51). Jakožto vždy podmíněné netematickou přítomností pozadí je perceptivní vědomí jakéhokoli tématu vždy „nepřímé“ a „převrácené“ (60), na rozdíl od vědomí v tradičním smyslu, které je z principu předmětně orientované, tematické a prrímé.

Významy vnímaného světa tak jsou zcela jiného druhu než významy myšlené (a $\mathrm{v}$ řeči vyjadřované) proto, že jsou principiálně neoddělitelné od uspořádání, ve kterém se objevují, a nelze je tak chápat jako subjektem intencionálně držená významová jádra, rozumu principiálně př́istupné podstaty. Zkušenost s perceptivními významy nelze chápat jako „udílení smyslu“ či konstituci (Sinngebung, Auffassung als, 55). Perceptivní smysl není vnímajícím „vlastněn“ jako v prrípadě inteligibilního významu (66), nýbrž je jím spíše , vykonáván“ (pratiqué, 50). Smyslově pocit’ovatelný význam je dán jako určitá „koherentní deformace našeho universa zkušenosti“" a našeho styku se světem, aniž bychom mohli vyslovit její princip. ${ }^{19}$ Je „,modulací určité dimenze“, „odchylkou“ od určité normy, která stejně jako odchylka sama není dána, nýbrž je skrytě předpokládána na pozadí (56).

Stručně shrnuto, vlastnosti vnímaného předmětu podle Merleau-Pontyho analýzy „souvisejí“ s jeho místem, mají na něj „vazbu“, jsou to „vázané“ významy, „,nevýslovné“ struktury - na rozdíl od významů myšlených vědomím a vyjadřovaných v řeči, které jsou (alespoň globálně vzato, v prvním přiblížení) „,nezávislé“ na svém kontextu, „,bez vazeb“, a $\mathrm{z}$ toho důvodu takř́kajíc připravené $\mathrm{k}$ tomu, aby byly tematicky vysloveny a uchopovány vědomím jako jsoucí o sobě.

19 M. Merleau-Ponty, Résumés de cours, str. 12. 


\section{Vyjadřování mezi vnímajícím a vnímaným}

Tento způsob danosti perceptivního významu a jeho vztah k vnímajícím nyní Merleau-Ponty nově shrnuje za pomoci pojmu vyjadřování. Platí-li, že smyslová „danost poukazuje na tělo, které je třeba mít“ (indique le corps qu'il faut avoir), $\mathrm{k}$ tomu, aby mohla být vnímána, a zároveň že „tělo završuje danost“ (80), tedy že smysl danosti krystalizuje pouze v kontextu těla, jeho patřičného postavení a jeho exploračních pohybů, pak je podle Merleau-Pontyho ,mezi smyslově pocit'ovatelnými [jsoucny] a vnímajícím orgánem vztah vyjadřování“ (rapport expressif, 49). Lidské tělo „má charakter výrazu“ (est expressif) v tom smyslu, že každé jeho gesto vykresluje a rozvíjí určitý svět (58), takže lze zároveň říci, že „identita věci je ekvivalentní škále gest, které k ní vedou“(58).

Vnímat význam, tj. figuru na pozadí, odchylku od určité normy, může pouze tělo „projikující“ se do světa, „zabydlující“ se ve světě tím, že při svém fungování privileguje některé jeho oblasti, které tak získávají „systematickou platnost“ (58), „nabývají hodnoty dimenzi““ (50) (napřr. zdi jako meze mého pohybu). Význam těchto prvků pak na druhé straně nemůže existovat o sobě, je svázán s tělem a tím, co a jak ono privileguje. Proto platí, že když svým tělesným postojem a pohybem adoptuji určitou perceptivní normu, ,vyjadřuji svět či on vyjadřuje mne“ (58). Jestliže na jedné straně „na věcech vidíme něco, co je zjevně výrazem subjektu“ (176), a na druhé naše tělesné postavení odpovídá určité konfiguraci světa, a tedy na ni odkazuje, pak ,mezi vnímaným a námi je vztah vyjadřování“ (50). Odtud Merleau-Ponty činí silný závěr, že „vnímání je tedy již vyjadřování“, ${ }^{20}$ že ,vyjadřování je podstatou perceptivního vědomí“ (176).

Myšlenka, že určitému postoji těla odpovídá určitá konfigurace světa, hraje důležitou roli již ve Fenomenologii vnímání a níže uvidíme, které konkrétní popisy odtud nyní Merleau-Ponty přebírá a prohlubuje. Pomocí pojmu vyjadřování ji však Merleau-Ponty systematicky formuluje až v přednáškách z r. 1953. ${ }^{21}$ Změna pojmosloví, jíž jsme svědky ve vztahu

20 Tamt., str. 14.

21 Ve Fenomenologii vnímání Merleau-Ponty sice již také mluví o vyjadřování, resp. výrazu (expression), ale až na několik náznaků ne ve smyslu vzájemné reference vnímajícího a vnímaného. V souladu s konvenčním užitím slova tím míní projev, díky němuž si osvojujeme nový význam, který však zároveň tento význam vytváří, nikoli pouze aktualizuje či prezentuje navenek (srv. tamt., str. 233). E. de Saint-Aubert ve své knize Être et chair. Du corps au désir: L'habilitation ontologique de la chair (Paris 2013, str. 57) uvádí, že v tomto novém, výrazně originálním smyslu Merleau-Ponty pojem poprvé používá v tzv. Mexických přednáškách z r. 1949 (ne- 
k Fenomenologii vnímání, není samoúčelná a má nám právě pomoci zbavit se zbytku intelektualistických předsudků (,opustit pojem vědomi“"). ${ }^{22}$ Zbavíme-li se důsledně intelektualistického slovníku a pojmů zděděných $\mathrm{z}$ této tradice a budeme-li místo toho chápat vnímání jako vzájemné vyjadřování vnímajícího a vnímaného, měla by nám právě tato homologie v obou kontextech umožnit navázat analýzu vnímání na analýzu kulturní symbolické produkce.

\section{Přehodnocení vztahu vnímání a myšlení, př́rody a kultury}

Merleau-Ponty konkrétně píše, že cílem zavedení pojmu vyjadřování je „na základě redefinování vnímání a smyslu obnovit jednotu a současně odlišnost světa vnímaného a světa inteligibilního“ (45). To přesněji znamená, že je v první řadě třeba vyhnout se dvěma podobám reduktivního přístupu $\mathrm{k}$ těmto rovinám zkušenosti, tj. tomu redukovat myšlení na vnímání (senzualismus) nebo vnímání na myšlení (intelektualismus). Výše jsme viděli, že vnímání má zásadně jinou strukturu než myšlení ve smyslu držení určených významů, že je tedy nelze vykládat jako jeho rudimentární formu. Na druhé straně redukce na senzorický „,pozitivismus vnímání“ (46) je podle Merleau-Pontyho sama absurdní, protože patřičně prozkoumané vnímání právě ukazuje, že vnímaný předmět vnímání samému uniká, že si vyžaduje vlastní překročení, a že tedy není žádná pozitivní matérie, na kterou by bylo možno ho redukovat. „Vnímání v úzkém (senzorickém) smyslu si žádá své vlastní vyjádření“"(45), což znamená překročení, a universum významů je tak na druhé straně ve vnímání již „anticipováno“. ${ }^{23}$ Merleau-Ponty opětovně tvrdí, že myšlení je „sublimací“ vnímání (45), tzn. že mezi „světem vnímání“ a „světem

publikovaný rukopis). Ve vydaném díle se tomuto způsobu užití poprvé přibližuje zřejmě v Próze světa, která vznikala z největší části v průběhu r. 1951. Srv. M. Merleau-Ponty, La prose du monde, např. str. 110: „každé vnímání ... je již prvotním vyjadřováním" (expression primordiale).

22 Je třeba si povšimnout, že v přednáškách z r. 1953 Merleau-Ponty přebírá z Fenomenologie vnímáni řadu konkrétních popisů (prostor, hloubka, pohyb), které dále prohlubuje, přitom však zcela nechává stranou její třetí část, jejímž cílem bylo právě podat filosofickou interpretaci subjektivity jako takové.

23 M. Merleau-Ponty, Résumés de cours, str. 12. 
významů“24 podle něj lze sledovat zároveň „přechod“ i „obrat“ (55), „povznesení“ a „překročení na místě“ (65).

Fenomén vyjadřování a jemu odpovídající pojem pro Merleau-Pontyho představuje takříkajíc neutrální půdu, jež je společná vnímání i myšlení, a proto umožňuje nereduktivním způsobem uchopit jejich rozdíl. Přesněji řečeno, vyjadřování na rovině řeči, tj. formulování významů, bez kterého není možné myšlení, je podle Merleau-Pontyho převzetím (assomption, reprendre) něčeho, co bylo přítomno ve vnímání, nakolik je již ono samo vyjadřováním. Vztah „vyjadřováni““ mezi vnímáním a vnímaným, píše Merleau-Ponty, ,pro nás slouží pouze jako úvod ke světu vyjadřování [ve ,vlastním smyslu“ $],{ }^{25}$ tzn. je prvním př́íkladem vyjadřovací aktivity, jíž posléze bude duch“, tj. myšlení (52). Ještě jinými slovy formulováno, „vyjadřování ve vlastním smyslu, to, kterého dosahujeme pomocí řeči, přebírá a zesiluje jiné vyjadřování, které odkrývá ,archeologie“ vnímaného světa“". 26

„Vše je vnímáním“ (tout est perception), tvrdí tak opakovaně Merleau-Ponty (např. 45, 54, 55). Přesněji, ,způsob př́ístupu k bytí, který existuje ve vnímání, je př́tomen všude“, na všech rovinách zkušenosti (45). Vnímání Merleau-Ponty nechápe jako pouze faktickou, senzorickou danost, nýbrž šíře jako určitý „,modus přístupu k bytí, přístup k leibhaftig gegeben“ (46), tj. jako zkušenost dávající svůj předmět v originále, „ztělesněný“. Je proto třeba nyní ještě přesněji zjistit, jakým způsobem chápat toto vnímání v širokém smyslu, jež by mělo dávat předmět v originále na všech rovinách zkušenosti. Na jedné straně je nutné, aby byla „naše představa vnímání ... rozšířena takovým způsobem, aby umožnila analýzu rozumu“ (55). Současně s tím je třeba provést analýzu struktur vlastních rozumu, jež by byla „stejného typu“ jako ta, která již byla provedena u vnímání a která ukáže „stejný typ organizace“ (54).

Jakým způsobem je tedy vnímání, tj. tělesně-perceptivní vyjadřování, „převzato“ kulturním vyjadřováním, a tak nakonec mluvením a myšlením? Vzájemné vyjadřování vnímajícího a vnímaného podle Merleau-Pontyho již umožňuje „otevřenost virtuálnu“ či „možnému“ (65). Existuje-li „synchronicita“ či „,synonymie určitých gest a určité krajiny,

24 Tamt., str. 11.

25 Pro jasnost doplňuji podle Résumés de cours, str. 12.

26 Tamt., str. 12-13. Tomu odpovídá i Merleau-Pontyho obecná definice pojmu vyjadřování, viz Le monde sensible et le monde de l'expression, str. 48: „Vyjadřování (expression) nebo výrazovost (expressivité) zde budeme chápat jako takovou vlastnost určitého fenoménu, díky níž se již z jeho vnitřního uspořádání dozvídáme o nějakém fenoménu jiném, aniž by tento byl zároveň či vůbec někdy dán.“ 
... vztah vyjadřování mezi zkoumajícím tělem a tím, co prozkoumává, např. [smyslovou] kvalitou“ (58), platí, že ,jsem v případě její nepř́ítomnosti schopný vytvořit její kvazi-přítomnost“, že mohu „za pomoci mého těla a jeho zasazení do pole [vnímatelného] realizovat kvazi-smyslové struktury“ (56). ${ }^{27}$ Tělo tak vytvárí „,virtuální prostor“ ve smyslu „systému korespondencí mezi vlastnostmi mého aktuálního pole a tím, čím by tyto vlastnosti byly pro mne $\mathrm{v}$ jiném postavení nebo pro někoho jiného“ (52; srv. 64 n.). Tělo je pro nás, jak Merleau-Ponty píše např. již v podkladech ke kandidatuře na Collège de France, ,mnohem více než nástroj či prostředek - je naším výrazem ve světě, viditelným tvarem našich intencí“. ${ }^{28}$ Tělo díky gestu přestává být pouze „danou strukturou“ (64), je nyní také „orgánem mimiky“ (64), aktivně se pohybuje a „obrací se zpět ke světu, aby jej označilo a ukázalo“ (52, srv. 64).

Tělesná praxis proto není pouze řešením zvnějšku přicházejících problémů, reagováním, nýbrž také „,propracováváním samotných podmínek“ existence (66). „Vyjadřování pomocí gesta“, píše Merleau-Ponty, „není překročením mé situace, nýbrž převzetím celého jejího smyslu“ (assomption de tout son sens, 65). Gesto, jež je stále určitou tělesně-perceptivní praxí, a nikoli intelektuálním vědomím významu, nás tak nepřenáší př́mo do roviny mimočasového světa podstat, avšak vyznačuje se jistou „Všudypřítomností“ (53). Jakožto výraz určité konfigurace světa, na níž může každé tělo participovat, překračuje horizont věcí vnímatelných pomocí těla jako pouhého prostředku vnímání, a proměňuje tak naši situaci.

\section{Vnímání prostoru a pohybu není možné bez vyjadřování}

Více než dvě třetiny přednášek Merleau-Ponty věnuje rozboru konkrétních tělesně perceptivních fenoménů, které mají tyto obecné filosofické pozice osvětlit na konkrétních situacích. Za tímto účelem interpretuje řadu popisů a experimentů zejména $\mathrm{z}$ oblasti gestaltpsychologie a neurologie, s přesahy také k psychoanalýze, psychopatologii apod.

Řada empirických zkoumání má pro Merleau-Pontyho pozitivní význam, často se ovšem také distancuje od jejich interpretací u původních autorů, protože podle něj mají redukcionistické tendence. První skupina

27 Podobné formulace lze nalézt již ve Fenomenologii vnímání, např. str. 265.

28 M. Merleau-Ponty, Un inédit de Merleau-Ponty, str. 39. 
fenoménů, které podle všeho nelze uchopit tak, že zvolíme empirickoobjektivistické nebo intelektualisticko-subjektivistické hledisko, je spojena s naším vnímáním prostoru. Naše zkušenost s orientací (nahoře-dole, vlevo-vpravo), viděním hloubky, blízkostí a dálkou či zdánlivou velikostí předmětů podle Merleau-Pontyho pokaždé poukazuje na to, že žádný z těchto fenoménů „není absolutní vlastností obsahů [vnímání], avšak ani pouze myšlenou organizací", protože stále zůstává bezprostřední smyslovou daností (77). ${ }^{29}$ Jde tak spíše o to, že vnímající tělo a vnímaný předmět spolu tvoří „systém“ (78), tj. celek, v jehož rámci se vzájemně ,vyjadřují“.

Konkrétně tak např. vertikální, vzpřímená orientace podle Merleau-Pontyho není ,výhradně vázána ani na vlastnosti světa ani na postavení těla“ (78), protože i když jsou podmínky v tomto ohledu stejné, orientace může být různá (srv. 57). Orientace spíše závisí na součinnosti systému těla a systému světa a bez jejich společného „optimálního fungování“ (78) dochází k deformaci vnímaného prostoru: Neodpovídá-li postavení našeho těla tomu, co si žádá „,vzpř́ímený“ svět, máme vjem „šikmé“ orientace, stejně jako $v$ prípadě, kdy struktura světa neodpovídá tomu, co pro nás doposud bylo normou „,vzpř́meného“ postavení těla. Jelikož má tato součinnost dynamický charakter, tzn. že to, co vnímáme jako „vzprrímené“" nebo „šikmé“, se může měnit, není vnímání orientace otázkou určitých vlastností těla nebo světa, ani otázkou interpretace vjemů (např. vizuálních ve světle taktilních). Závisí spíše na tom, jak si tělo osvojuje prostor a jak prostor odpovídá fungování těla, což podle Merleau-Pontyho ilustruje způsob, jímž je jedno vyjadřováno v druhém jako v pozadí stojící prvek, na nějž každý z nich implicitně odkazuje svým vlastním uspořádáním.

Merleau-Ponty však pro svůj výklad vnímání jako vyjadřování považuje za nejvýznamnější jiný fenomén - totiž pohyb. Pohyb, tvrdí Merleau-Ponty, ,ještě lépe než problém [smyslové] kvality nebo prostoru ospravedlňuje přepracování problému vnímání a pojmu subjektu“ (181), protože na rozdíl od věci, která „,na první pohled existuje o sobě“, odhaluje naznačenou „koexistenci“ těla a toho, co prožívá (181).

Merleau-Ponty nejdříve věnuje široký prostor výkladům, jež by nám měly umožnit vrátit se k pohybu jako fenoménu, tj. přestat jej chápat objektivizovaně, jako změnu místa se sebou identického předmětu v o sobě jsoucím prostoru. Myslíme-li pohyb takto, je vůči pohybovanému vnější,

29 Při rozborech hloubky, orientace a pohybu (viz níže) Merleau-Ponty navazuje na analýzy z Fenomenologie vnímání, str. 307-345. 
což vede $\mathrm{k}$ tomu, že myšlenkově ztrácíme to, co je nám perceptivně dáno - právě pohybující se samo a pohyb jako jeho integrální součást. $\mathrm{Na}$ druhé straně nestačí ani vrátit se k pohybu „žitému zevnitř““, našemu vlastnímu pohybu (Bergson), protože jde právě o to pochopit, jak je možná nedílnost pohybu $\mathrm{v}$ předmětném, tedy vůči nám vnějším světě. Proti těmto objektivistickým a subjektivistickým př́istupům proto Merleau-Ponty staví popisy gestaltpsychologie, které podle něj umožňují suspendovat naše kladení objektivního světa a pohybu jako události v něm a navrátit se k pohybu „ve stavu zrodu“ (93), tj. k samé fenomenální struktuře pohybu.

Gestaltpsychologické studie stroboskopického pohybu v tomto smyslu ukazují, že pohyb je „výsledkem vnitřního uspořádáni“ perceptivního pole (102), figurou na pozadí, tedy že není nutné, ba ani přesné vykládat jej na základě předpokladu nějakého pohybovaného jsoucna. Ani prvky pole samotného ovšem nelze chápat ve smyslu objektivně existujících př́čin, které by na psychické úrovni deterministickým způsobem působily vjem pohybu (jak se domnívá sama gestaltpsychologie). Jelikož smysl jevu jako celku je částečně závislý také na smyslu prvků pole, gestaltpsychologie je nucena svůj objektivistický determinismus doplnit zásahem intelektuálně chápaného vědomí, které na základě identifikace a posouzení předmětu dodává to, co nelze odvodit z objektivisticky chápaného pole. Podle Merleau-Pontyho ovšem organizace pole neexistuje ,,ani ve třetí osobě, ani v první“ (104), opět se vymyká kombinaci objektivních a subjektivních determinant.

Experimenty realizované Albertem Michottem ${ }^{30}$ již podle Merleau-Pontyho ukazují, že pohyb sám o sobě „odkrývá bytí“ (102), aniž bychom vůbec kladli objektivní jsoucno a aniž bychom měli intelektuální vědomí o předmětu. Michottovy stroboskopické projekce totiž např. ukazují, že série tří obrazů abstraktních čar může být vnímána jako pohyb živého tvora (např. plazení, plavání), aniž by vnímající subjekt měl nějaké znalosti z oblasti biologie či vůbec jakoukoli představu o konkrétním zvířeti. Jakmile se objeví „uzavřený tvar, moje tělo se s ním identifikuje a dochází k Einfühlung (vcítění) do jeho vztahů s okolím“ (197); pohyby plazení či plavání nám nepřipomínaji červa nebo žábu (107), jsou jednoduše „výsledkem variace vnitřního členění figury“ (105). Mezi glo-

30 A. Michotte, Perception de la causalité, Louvain 1954. Srv. M. Merleau-Ponty, Le monde sensible et le monde de l'expression, zejm. str. 101 a 181. Michottovy experimenty Merleau-Ponty shrnuje rovněž ve svých pozdějších přednáškách o přírodě, srv. M. Merleau-Ponty, La Nature. Notes. Cours du Collège de France, Paris 1995, str. 205-206. 
bálním smyslem uspořádání pole a jeho prvky určitým způsobem vztaženými k sobě tak podle Merleau-Pontyho panuje vztah reverzibility či „ekvivalence“, která nepředpokládá, nýbrž naopak sama o sobě teprve přináši vědomí určitého předmětu.

Tuto myšlenku chce Merleau-Ponty dále potvrdit pomocí rozboru príkladů zpomaleného a zrychleného pohybu. ${ }^{31}$ Ta samá konfigurace perceptivního pole, která v nás vyvolává dojem určitého typu předmětu, např. živočicha, působí dojmem rostlinného, či dokonce anorganického jsoucna, je-li zpomalena. Zpomalené pohyby lidí zase působí nesrozumitelným, neskutečným dojmem, a zrychlené rostliny naopak jako by začínaly dělat gesta jako živočichové. Smysl daného jevu obdobným způsobem mění rovněž variace dynamiky zvukového doprovodu.

Platí-li, že při změně kadence vnímaného pohybu dochází ke změně způsobu, jímž chápeme byti předmětu, tj. zakoušíme jiný předmět, pak je podle Merleau-Pontyho pohyb perceptivní fenomén, který podobně jako orientace nebo hloubka nemůže existovat „o sobě“, nýbrž jej lze vnímat jedině na základě „určité antropologické projekce do věcí“ (182). Vnímající subjekt uchopuje vnější pohyb, resp. momenty perceptivního uspořádání, z nichž vyvstává, jako určitou událostní jednotu proto, že se vztahuje k prostoru a pohybuje se v něm (avoir prise sur l'espace, 112). To, co umožňuje podržet jednotlivé prvky pohybu u sebe a uchopit je jako určitý celkový smysl, tedy jako určitý předmět, je tak neoddělitelné od subjektu, který je sám pohyblivý a který je schopný určitého pohybového „projektu“. Ve vnějšku vnímaný pohyb se na straně vnímajícího dotýká určité „klaviatury“ možností či „ozvučné desky“ (117), jež mu na základě svého předchůdného uspořádání zpětně propůjčuje jeho celkový způsob organizace. O něco radikálněji řečeno, „naši schopnost pohybu“ je třeba chápat jako ,základ pohybu předmětů“ (120); ,smysl [vnějšího] pohybu je motorický projekt“, vnější ,pohyb, jeho smysl, jeho charakteristický chod chápeme na základě hybných možností vlastního těla“ (119). Podle Merleau-Pontyho lze nakonec mluvit i obecněji o tom, že vnímaný předmět mobilizuje nejen naše potenciality motorické, ale i životní, jak lze ukázat např. na tom, jak na nás působí různé druhy prostoru (čas, tj. také pohyb, napr. plyne jinou rychlostí v závislosti na světelnosti prostoru). ${ }^{32}$

31 Opírá se přitom zejména o popisy Jeana Epsteina (L'intelligence d'une machine, Paris 1946) a o film Jeana Viga Trojka z mravu (Zéro de conduite, 1933), kde se vyskytuje známá scéna se zpomaleným pohybem postav.

32 Kromě gestaltpsychologie se Merleau-Ponty inspiruje např. esejistickým textem J. Paulhana, La peinture moderne ou l'espace sensible au coeur, in: La Table Ronde, 2, 1948, str. 267-280. 
Merleau-Ponty shrnuje svou myšlenku následujícím způsobem: „Uspořádání tvaru se na mne obrací a dotazuje se mých vztahů s prostorovým okolím, Sinngebung (udílení smyslu), ke které dochází, je odpovědí mé prostorovosti na to, co v uspořádání výjevu vybízí k Einfühlung (vcítění)“ (189). Něco jako vnímání pohybu je tedy možné proto, že „mezi mnou (mým tělem, mými [smyslovými] poli) a výjevem je vztah vyjadřováni" (rapport expressif), že „,zaujmout nějaký postoj pokaždé znamená schopnost být v určité situaci a každý výjev je stopou nějakého postoje“"(125). Vnější pohyb a motorický subjekt jsou tedy výrazem jeden druhého, protože vnější pohyb vyvolává variaci motorické dimenze subjektu a bez existence motorického subjektu by nebyl vnější pohyb.

\section{Subjektem vnímání je tělo jakožto „tělesné schéma“}

Má-li se má vlastní časoprostorová nedílnost a pohyblivost odrážet ve věcech tak, jak se to podle všeho ukazuje např. na fenoménu pohybu, musí tělo být schopné tuto vazbu nést a náležitým způsobem ji adaptovat ve vztahu ke světu. Proto je klíčovým bodem druhé části přednášek původně neurologický pojem ,tělesného schématu“, 33 tj. těla, které stojí v pozadí všech našich perceptivních aktů jako jejich referenční norma, a je v nich proto v tomto smyslu vždy „vyjadřováno“.

Merleau-Ponty klade pojem „schéma“ výslovně do protikladu k představě „obrazu“, aby tak zdůraznil, že schéma není reprezentace ve vědomí. ${ }^{34}$ Tělesné schéma podle něj jednak není předmětem myšlení či

33 Zásadní roli pro Merleau-Pontyho hraje kniha P. Schildera The Image and Appearance of the Human Body: Studies in the Constructive Energies of the Psyche, London 1935. K tělesnému schématu srv. rovněž Fenomenologii vnímání, zejména str. 134-137 a 290-294. Zde se již Merleau-Ponty distancuje od původní asocianistické i pozdější formalistické definice tělesného schématu, avšak v r. 1953 se již mnohem více věnuje tomu, jak lze tělesné schéma určit pozitivně a dynamicky. Ve Fenomenologii vnímání vychází pouze z raných prací neurologů Heada, Lhermitta a Schildera, nyní studuje novou literaturu, zejména výše citovanou Schilderovu knihu.

34 Sami neurologové, zejm. P. Schilder, ne vždy dokáží jasně formulovat, zda, resp. nakolik se schéma liší od obrazu. Tento stav v současné literatuře kritizuje zejm. S. Gallagher (např. How the Body Shapes the Mind, Oxford 2005, str. 17-40), který se sice v tomto smyslu shoduje s Merleau-Pontym, avšak pojetí subjektivity a těla obou autorů je podle všeho značně odlišné. Pro kritické srovnání pojetí tělesného schématu u obou autorů srv. např. E. de Saint-Aubert, Etre et chair. Du corps au désir: L'habilitation ontologique de la chair, str. 43-59; J. Halák, Merleau-Ponty 
poznání (140), je vnímatelné a názorné jako nákres či plánek; zároveň však má v jistém smyslu obecnou hodnotu, protože „vyznačuje, co je podstatné" (133). Tělesné schéma tedy není faktem či předmětem, který bychom pouze konstatovali, protože z něj vychází určitý smysl, jemuž se podřazují všechny jednotlivosti, avšak tento smysl zároveň není dán formou intelektuálního, pojmového vědomí.

Tato „předlogická“, „laterální“ jednota těla (126) vyplývá z toho, že části těla se „vzájemně implikuji““, tj. že funkčně, prostorově a smyslově „koexistuji““ (133). To se podle Merleau-Pontyho ukazuje např. na tom, že je možné ztratit schopnost pojmově si zpř́tomnit a jmenovat prostorové umístění částí svého těla, aniž by subjekt zároveň přišel o praktický prŕstup k nim (tzv. autotopoagnozie). To však neznamená, že jednota těla je jednotou fyzické věci „tělo“, nýbrž že je jednotou orgánů či údů (zejm. aktivních částí těla jako ruce a nohy). Potvrzuje to fenomén fantomové končetiny, kdy je zachována jednota jednání a kdy „pokračuje celková aktivita“ subjektu (137), i když „část těla, o kterou se má toto jednání opřít, objektivně neexistuje“ (140). ${ }^{35}$

Jednotu tělesného schématu tak lze pozitivně popsat v první řadě jako jednotu určité praxis (138), ,,jednotu činnosti“ (150). Tělo je ,postoj k“, „otevřenost vůči cílům“ (133), kterou máme k dispozici, nakolik jsme schopni čelit nějaké situaci nebo něco dělat. Přesněji řečeno, tělo je ,výchozím bodem pro určitou činnost ve světě“, „rejstříkem“, do kterého jsme vepsáni v našem vědomém životě a do kterého se „zapisujeme“ veškerou svou další činností. ${ }^{36}$ Tělesné schéma ,je vždy orientováno vůči privilegovaným pozicím, normám“ pro realizaci určitých činností, a „vědomí, které o něm máme, je zejména vědomím odchylky od těchto norem“ (139). ${ }^{37}$ Nejedná se zároveň o jednotlivé činnosti působící na jednotlivé předměty, nýbrž spíše o ,typy činností či gest““, jako je napřr. „uchopit“" něco (150). Mít tělo proto za normálních okolností znamená bezprostředně disponovat tělem jakožto místem, odkud vychází naše iniciativa vůči věcem, a mít věci znamená nacházet své tělo jako potenci na ně působit, tzn. zažívat ,soulad (Deckung) určitého stylu aspektů svě-

on Embodied Subjectivity from the Perspective of Subject-Object Circularity, in: Acta Universitatis Carolinae Kinanthropologica, 52, 2016, str. 33-39.

35 Srv. již M. Merleau-Ponty, Fenomenologie vnímání, str. 110 nn.; zde obsažené rozbory nicméně Merleau-Ponty v přednáškách značně prohlubuje.

36 M. Merleau-Ponty, Résumés de cours, str. 16.

37 Merleau-Ponty se zde opírá o formulace H. Heada, srv. Le monde sensible et le monde de l'expression, str. 138-139. 
ta (něčeho, co chceme udělat) a pozadí, odkud tato iniciativa vychází" (150).

Z hlediska prostoru je pak tělo „absolutním zde“ (129), „před-objektivní prostorovostí““ (138), „lokalitou“ samou (150), nikoli pouze jedním z možných obsahů prostoru, jak by platilo, pokud by bylo předmětem. Je samo „zprostředkovatelem vztahu zde-tam“ (142), pozadím, vůči němuž vystupují předměty jako odchylky nadané smyslem „tam“. Lokalita mého těla a prostorové odchylky předmětů se vzájemně „ukazuji““(152).

Jakožto toto pozadí činnosti a prostorových vztahů tělesné schéma „není vnímanéc, je „před explicitním vnímáním“ (143) a u normálního člověka je jeho tematická danost nadbytečná. Tělesné schéma je naopak vůbec ,normou nebo privilegovanou pozicí, v protikladu ke které lze definovat vnímané tělo“ (143). Implicitní přítomnost těla na pozadí a jím nesenou prrítomnost světa negativně ukazuje např. tzv. ,japonská iluze“, specifická poloha těla, při které vizuální vjem našeho těla narušuje naši schopnost efektivně disponovat taktilním tělem. Při této iluzi vizuální tělesné schéma neodpovídá našim možnostem na rovině praxis, takže se naše vizuální tělo stává cizím předmětem v prostoru, který je od nás odpojený a který můžeme pouze postupně bod po bodu nalézat pomocí pokusů a omylů. Podobně př́ípady autotopoagnozie ${ }^{38}$ ukazují, že nutnost pomocí pátracích pohybů „hledat“ své tělo či „usuzovat“ na jeho polohu z určitých vnímaných aspektů (např. tlak židle) je patologickým projevem a kompenzací ztráty samozrrejmé prrítomnosti těla na pozadí. Normální subjekt nemá tělo dáno předmětně, např. neví, která část těla bude působit na kterou část předmětu, avšak toto pozadí je pro něj zde, k dispozici, což umožňuje nevěnovat se jemu, nýbrž právě činnosti ve světě.

Nejenže původní př́itomnost těla jakožto základny činnosti pro nás nemá předmětný charakter, je naopak dokonce třeba tvrdit, že ,je projektem“ (142), jelikož struktura tělesného schématu se proměňuje korelativně s naším úsilím. Variace vnímané lokalizace těla ukazují, že se tato lokalizace nekryje s objektivní polohou těla, nýbrž se při činnosti posouvá ve směru tonusu (143). Tělo ve smyslu tělesného schématu se tak nachází nikoli tam, kde lze tělo objektivně konstatovat, nýbrž „tam, kam jsme připraveni je umístit“, kde jsme s to zaujmout patřičný postoj

38 Srv. např. známý př́ípad veterána Schneidera, tamt. str. 139 nn., a M. Merleau-Ponty, Fenomenologie vnímání, str. 139 nn. V současné filosofické literatuře patologie tohoto typu popisuje a interpretuje rovněž Gallagher, srv. např. S. Gallagher - J. Cole, Body Schema and Body Image in a Deafferented Subject, in: Journal of Mind and Behavior, 16, 1995, str. 369-390. 
ve vztahu k nějaké činnosti či k něčemu, co chceme vnímat (139). Tělesné schéma na rovině svalového tonusu tak definuje „klidovou normální pozici, ve které bychom nic nevnímali jako figuru a vůči které je každá odchylka vnímána právě jako výslovné vnímání“ (143). Variace napětí tělesného schématu korelativně vzbuzují variace vnímaného světa, „tedy tělesné schéma je také určitá struktura vnímaného světa a ten v něm má své kořeny“" (143).

\section{Transfigurace tělesného schématu}

Z cirkulární vazby mezi tělesným schématem a činností, pro niž je pozadím, tj. výchozím bodem, prostorovou referencí a vytyčením roviny nulového úsilí, vyplývá také to, že jednota tělesného schématu je dynamická. Tělesné schéma je „mobilizovatelné“ (142), „zůstává otevřené“ (139), je „dourčováno činností“ (139) a „v klidu je nečleněné“ (142). Merleau-Ponty se v návaznosti na neurologické rozbory věnuje řadě patologických podob tělesného schématu, zejména apraxiím, které dynamický charakter tělesného schématu potvrzují nejprve negativním způsobem. Ukazuje se to na př́padu známém již z Fenomenologie vnímání, ${ }^{39}$ válečném invalidovi Schneiderovi, který ,nenalézá části svého těla“, je-li v klidu (139), avšak pomocí „přípravných“ „automatických“ pohybů celého těla je schopen ,postupně upřesnit“ (141) jeho umístění v prostoru, „reaktivovat tělesné schéma“ (142) a nakonec zjistit polohu částí svého těla. Takto odhalenou transfiguraci těla $v$ činnosti a jí odpovídající „stupně artikulace tělesného schématu“ (151) lze podle Merleau-Pontyho obdobně sledovat na jednotlivých fázích spánku, resp. probouzení, které po vzoru několika neurologických autorů interpretuje jako apraxii (hluboký spánek jako totální apraxie).

Při apraxii je vazba tělesného schématu jako pozadí a výchozího bodu činnosti a této činnosti samé „rozpojena“ (dissociation) (144), tělesné schéma a svět již nejsou „zapřažené“ (engrenage) do sebe navzájem (155). Apraxie je tedy stav, kdy subjekt ví, co by měl udělat (gnósis), je schopen úkol slovně formulovat (fasis), ale toto vědomí, ,intelektuálně definovaný úkol“ (144), v něm nevyvolává realizaci činnosti (praxis). Že je vůbec něco takového možné, podle Merleau-Pontyho souvisí s tím, že tělesná praxis sedimentuje, tj. že naše praktické tělesné schéma se obohacuje např. vizuálním schématem, na jehož úrovni se tělo již stává

39 Srv. M. Merleau-Ponty, Fenomenologie vnímání, str. 58 a zejm. 139 nn. Merleau-Ponty čerpá zejm. z prací A. Gelba a K. Goldsteina. 
předmětem, ke kterému se vztahujeme jinak než čistě na rovině praxis (148). Subjektu trpícímu apraxií pak chybí vazba mezi tímto zpředmětněným, sedimentovaným tělem, kterého se týká gnósis či fasis, a tělem jako tělesným schématem, které je výchozím bodem určité praxis (podobný stav navozuje např. výše zmíněná japonská iluze, která odpojuje naše vizuální schéma od praktického).

Patologické fenomény tohoto typu podle Merleau-Pontyho vyžadují, abychom nově promysleli obecnou (nepatologickou) podobu vztahu „praxis k poznání, gnósis, pojmovému vědění“ (152) a nakonec i řeči (fasis). Je možné uvažovat jednoduše o tom, že problém na jedné rovině je př́činou problémů na rovinách ostatních, jak by tvrdila např. jejich „intelektualistická“ interpretace? Merleau-Ponty se problém pokouší vyřešit zejména pomocí rozboru různých typů vazeb, resp. relativní nezávislosti mezi různými typy apraxií a agnozií. Na základě poznatků neurologie nakonec konstatuje „originalitu praxis“, tj. „relativní autonomii způsobu, jímž je nám svět př́itomen pomocí pohyblivosti“ (154). Obtíže na rovině praxis mají totiž $\mathrm{v}$ některých př́padech za následek obtíže na rovině gnósis, můžeme se ale setkat jak s apraxií bez agnozie, tak s agnozií bez apraxie. Neplatí tedy ani, že by všechny apraxie byly agnozie, ani že by byly oba typy obtíží naprosto nezávislé. Merleau-Pontyho prvním nejsilnějším závěrem tak je na první pohled neuspokojivé konstatování, že mezi agnozií a apraxií existuje jak ,spojitost“ (connexion), tak „oddělenost“ (disjonction, 157), tedy že je spojení a relativní nezávislost i mezi praxis a gnósis.

Přesný vztah praxis a gnósis zůstává pro Merleau-Pontyho otázkou až do konce kursu a na základě jeho hutných shrnutí různých patologií lze mnohdy jen s obtížemi dovodit, jaký filosofický závěr mají vlastně podporovat (resp. jestli vůbec nějaký). Výše vykázaný vztah mezi rovinami praxis a gnósis však alespoň vyřazuje možnost, že mezi problémy na obou rovinách je vztah prŕmé determinace. Merleau-Ponty tak nachází argument proti redukcionistickým pokusům objektivismu a intelektualismu a problém se dostává na novou rovinu, kde je třeba praxis i gnósis vyložit jako dvě k sobě vztažené modality našeho originárního vztahu ke světu, jejž Merleau-Ponty nazval vnímáním.

Dvojznačný vztah mezi praxis a gnósis lze ilustrovat na konkrétním př́kladu vztahu k prostoru: Na jedné straně je poznávací vztah k prostoru fundován tělesnou praxí, protože základní pojmy jako bod, plocha, kontura mají vůbec nějaký smysl pouze pro subjekt prakticky existující v prostoru a zasazený do nějakého místa v něm; na straně druhé je superstruktura „poznání“ relativně nezávislá, protože operace s pojmově 
přístupnými prostorovými symboly jsou v určitých patologický př́ípadech možné i přesto, že na rovině praxe subjekt trpí těžkými poruchami. Superstruktury na rovině gnósis tedy mají význam zisku či výdobytku praxis (acquis, acquisition) $(141,161)$, který zůstává, i když je praktická infrastruktura, ze které vzešly, poškozena. Merleau-Ponty tak konstatuje, že „superstruktury se vyznačují vlastní stabilitou“ (solidité propre des superstructures, 157), která vzniká „,sedimentací“ praxis (např. 148, 151, 157, 201).

Zároveň ovšem platí, že vyšší rovina, kterou vnímáme jako takovou sedimentaci infrastruktury praxis, si zachovává svou plnohodnotnou podobu a takřríkajíc zůstává živá, pouze pokud se opírá o nějakou část tělesného schématu, která je schopná v aktivitě praxis pokračovat. Platí sice, že pokud je infrastruktura praxis poškozena, superstruktura gnósis může „maskovat“ její zhroucení (148, 157-158, 199), tj. subjekt je např́. schopný i nadále provádět operace s pojmy vyjadřujícími prostor, i když nemá př́stup ke konkrétním praktickým aktivitám, díky nimž mohly vzniknout a které jsou s to vyjadřovat. ${ }^{40}$ Avšak sama superstruktura v takovém př́ípadě podle Merleau-Pontyho zásadně mění svůj charakter, protože pokud integrita gnósis nepředpokládá rázem integritu infrastruktury praxis, předpokládá alespoň schopnost přistupovat k rovině gnósis konstruktivním, produktivním způsobem (148). Ztrácí-li subjekt tento aktivní život na rovině gnósis, tj. určitou praxis druhého řádu, ${ }^{41}$ stává se superstruktura skutečně už jen pouhou maskou, zdáním gnósis. Merleau-Ponty opět používá popisy chování zraněného Schneidera, z nichž je zřejmé, že si sice uchoval základní schopnost práce s pojmy a může uživat řeč, avšak ztratil schopnost $\mathrm{k}$ těmto aktivitám přistupovat produktivně, spontánně, s iniciativou, není schopný improvizovat apod. (157). ${ }^{42}$

Ještě konkrétněji např. analýza Gerstmannova syndromu, při kterém postižený trpí zároveň sníženou schopností provádět matematické opera-

40 Obdobný příklad týkající se rozlišování, resp. jmenování barev Merleau-Ponty rozebírá na základě prací Gelba a Goldsteina, Fenomenologie vnímání, str. 244.

41 Srv. M. Merleau-Ponty, Le monde sensible et le monde de l'expression, str. 149: „vyšší formy vyjadřování (rozpoznávání symbolů a zacházení s nimi) jsou stále fakta praxis“; tamt., str. 127: „V principu jsou praxis a gnósis synonymní. Ale gnósis není praxis na stejné rovině.“

42 Schneider vždy postupuje podle předem daného plánu, což se týká i jeho způsobu užívání řeči: srv. M. Merleau-Ponty, Fenomenologie vnímání, zejm. str. 177 a 248. Srv. také Merleau-Pontyho popis afázie, tamt., str. 224. 
ce a rozlišovat prsty rukou a strany, ${ }^{43}$ podle Merleau-Pontyho odhaluje, že sice zajisté nemyslíme rukama, ale že nemyslíme ani bez „transfigurovaného“ těla (162), těla jakožto „nositele“ významů, infrastruktury praxis, jak jsme ji výše popsali na vlastnostech tělesného schématu. Gesto vykonané rukou „neobsahuje myšlení“, ale „ruka je nutná k myšlení“ přinejmenším proto, že je frázuje, člení a zasazuje do světa (162) právě tím způsobem, jakým určité postavení těla při vnímání odpovídá krajině, kterou se pokoušíme vnímat. Tuto oporu tělesného schématu je tak možno zredukovat či ochudit, ale nikoli zcela zrušit, pokud má být myšlení v plném slova smyslu možné (201). Jinými slovy, netrpí-li lidé, kteří přišli o ruku, jež hraje důležitou roli při orientaci v prostoru, nutně prstovou agnozií (201), musel u nich roli, kterou hrála ruka v tělesném schématu, přejmout jiný orgán. Ruka v tomto smyslu tedy „není ruka-část, empirická ruka, kus z masa a kostí“, nýbrž „ruka, nakolik je součástí aktivního těla a tělesného schématu“ (201). Ruka v tomto smyslu je „nositelem lidského významu“ (est chargée de signification humaine, 201). Merleau-Ponty tuto svou pozici shrnuje následovně: „tělo je nositelem (porteur) neomezeného počtu symbolických systémů ..., jejichž vnitřní rozvíjení bezpochyby přesahuje význam ,přirozených“ gest, avšak tyto systémy se hroutí, pokud tělo přestane členit jejich vykonávání a zasazovat je do světa a do našeho života." 44

Mezi rovinami praxis a gnósis je tedy podle Merleau-Pontyho „fundamentální vztah“(157), protože poškození na jakékoli z rovin se nakonec vždy nějak odráží na všech ostatních (158). Tyto postoje či poznávací modality bychom proto měli chápat jako „póly“ jednotného lidského vztahu ke světu, jako projevy jedné funkce či síly uskutečňující se na různých úrovních $(147,158) .{ }^{45}$ Jakkoli jsme tedy výše viděli, že Merleau-Ponty chce tvrdit, že „vše je vnímáním“, a později i to, že vnímání má původně charakter praxis neboli pohyblivosti (mobilité, motilité), nelze podle něj zastávat názor, že by „teorie byla bezprostředně totožná s praxis“(199). Intelektuální funkce podle něj není nadřazená praktické, ale ani obráceně „neplatí, že by theórii bylo možno redukovat na praxis“ (199). Nelze vůbec pomýšlet na to, že redukujeme jedním nebo druhým

43 M. Merleau-Ponty, Le monde sensible et le monde de l'expression, str. 149, pozn. 1: „Gerstmannův syndrom je soubor symptomů vyznačující se spojením prstové agnozie, nerozlišování pravé a levé strany, agrafie a akalkulie.“

44 M. Merleau-Ponty, Résumés de cours, str. 18; v podobném smyslu M. Merleau-Ponty, Le monde sensible et le monde de l'expression, str. 158.

45 Srv. již M. Merleau-Ponty, Fenomenologie vnímání, str. 242. 
směrem a Merleau-Ponty se explicitně vyjadřuje v tom smyslu, že „takovou redukci nem[á] v úmyslu provádět“ (199). Místo toho, že by jedna rovina pohlcovala druhou, platí, že ,praxis do sebe začleňuje i theória, zahrnuje určitou theória nebo gnósis, jíž je základem (fond), již modifikuje a jíž je zpětně sama modifikována“ (141). Takto definovaný vztah mezi oběma rovinami odráží proces fundace, vyjadřování a sedimentace, který zároveň zůstává cirkulární.

Merleau-Pontyho původním záměrem bylo výsledky analýz patologií tělesného schématu potvrdit na základě studia způsobu, jímž se tělesné schéma specificky modifikuje za pomoci před-řečových výrazových aktivit, konkrétně výtvarného umění. Nakonec však toto téma zpracovává pouze velmi stručně při poslední přednášce a nemáme bohužel prostor se mu blíže věnovat. Obecně řečeno výtvarné umění a např. i film nás dovádějí $\mathrm{k}$ významu, který se $\mathrm{v}$ prostě vnímatelném světě nevyskytuje, tím, že specifickým způsobem mobilizují naše tělesné schéma (podobně jako vnímaný pohyb mobilizuje naše motorické potenciality). ${ }^{46}$

Na začátku jsem již naznačil, že na stejném principu podle Merleau-Pontyho funguje i řeč, tj. že je formulací a tematizací původně „,neartikulovaného významu“ (201). Řeč však již má ambici plně realizovat to, co na rovině výtvarného umění zůstává ne plně vyslovené (tacite): chce se „zmocnit významư", fixovat je (170). S nástupem řeči se podle Merleau-Pontyho „objevuje něco nového, co si zasluhuje zvláštní zkoumání“ (162, srv. 165), a proto se jí chce (a bude) věnovat v následujícím roce. ${ }^{47}$ Cílem přednášek o vyjadřování však nebylo analyzovat řeč (66), nýbrž pouze ukázat, že tělesné schéma je oporou myšlení (srv. např. 162, 126), jak jsme vysvětlili např. na Gerstmannově syndromu. Tomu na úrovni řeči odpovídá, že „systém mluvy“, o niž se opírá pojmové myšlení, je podle Merleau-Pontyho „zvlášt' křehkou superstrukturou tělesného schématu“ (164). Tak křehkou, že se fonematická struktura rozvolňuje či rozpadá paralelně $s$ dezartikulací na rovině praxis, což lze sledovat na jednotlivých fázích spánku, resp. probouzení jakožto stupňů apraxie. Fasis a praxis jsou tak podle Merleau-Pontyho ,paralelní jakožto funkce

46 Interpretaci přednášek o vyjadřování ve vztahu $\mathrm{k}$ filmu bylo věnováno několik studií v Chiasmi International 12, Philosophie et mouvement des images, Milano - Udine 2010.

47 Fixování významu za pomoci řeči, což de facto znamená jeho oddělení od jednotlivého projevu, je podle Merleau-Pontyho možné na základě toho, že v minulosti vydobyté významy v řeči ,sedimentuji““ (na rozdíl od významů formulovaných před-řečovými výrazovými prostředky). Srv. např. M. Merleau-Ponty, La prose du monde, str. 142 a 151. 
artikulující svět, který je vědomím ve smyslu bdění“ (163), jsou figurami „stejné existenciální modality“ (162).

Tento relativně krátký exkurs k paralelnímu charakteru praxis a fasis odhalitelnému za pomoci analýzy probouzení $(160-165,208-209)$ je jediným Merleau-Pontyho pokusem v přednáškách o vyjadřování tematicky uchopit přechod k řeči. Je ovšem na místě připomenout, že Merleau-Ponty v r. 1953 vede ještě druhý, paralelní kurs, jehož tématem je „literární užití řeči““. ${ }^{48}$ Obecně řečeno zde zkoumá, jak literatura pomocí systematické transformace řeči vydobývá nové způsoby lidské existence, čili jak myšlení na rovině literární řeči „transfiguruje“ náš před-literární život. Záměrem kursu „Problém mluvy“49 z roku následujícího (1953-1954) ve stejné linii bylo rozšírit saussureovský pojem mluvy a chápat ji jako obecnou ,pozitivní a dobyvatelskou funkci“ ${ }^{\circ 50} \mathrm{v}$ protikladu k představě řeči jako pouhé hmotné opory či záznamu „kategoriálního postoje“ "ducha. Merleau-Pontyho úvahy o řeči však vycházejí již z prací na Próze světa (kolem 1951) a po zbytek života je bude upřesňovat, např. v přednáškách o Husserlově Ursprung der Geometrie a Heideggerově Unterwegs zur Sprache (1959-1960). ${ }^{51}$

\section{Závěr: vyjadřování čili reversibilita - principiální motiv Merleau-Pontyho filosofie}

V úvodu jsem citoval z materiálů, z nichž je zřejmé, že již v době $F e$ nomenologie vnímání chce Merleau-Ponty chápat vztah mezi vnímáním a myšlením jako fundaci a překročení čili „sublimaci“. Při rekapitulaci přednášek jsme pak mohli vidět, jak Merleau-Ponty zpřesňuje a konkretizuje tuto ideu. Vysvětluje, jak ,infrastruktury“ praxis sedimentují do podoby relativně nezávislých ,superstruktur“ gnósis, které je zpětně modifikují, tj. detailněji člení, avšak zároveň jimi nepřestávají být nese-

48 Ke kursu byly vydány př́ípravné poznámky a shrnutí: M. Merleau-Ponty, L'usage littéraire du langage. Cours au Collège de France. Notes, 1953, Genève 2013; týž, Résumés de cours, str. 22-30.

49 K tomuto přednáškovému cyklu nebyly vydány žádné materiály kromě shrnutí, M. Merleau-Ponty, Résumés de cours, str. 32-42.

50 Tamt., str. 34.

51 M. Merleau-Ponty, La prose du monde, Paris 1969; týž, Notes de cours sur L'orgine de la géometrie de Husserl, Paris 1998 (přípravné poznámky k přednáškám). 
ny a jsou na ně odkázány ve své dynamice. Zároveň se tím dostáváme od „vzájemného“ vyjadřování těla a světa k vyjadřování „,ve vlastním smyslu“, jež je formulací doposud nedisponibilního významu, překročením naší tělesné situace. Viděli jsme, že v první polovině přednášek se Merleau-Ponty zabýval takř́ikajíc horizontálním, zrcadlovým vztahem mezi tělem a světem, jejich cirkulárním podmiňováním; v polovině druhé bylo již otázkou, jak tato rovina významu může být „,vertikálně“ dediferencována $\mathrm{v}$ patologii či převzata a dále strukturována na rovině různých typů kulturních významů, čímž dochází bud' $\mathrm{k}$ jejímu rozpadu (napřr. apraxie, spánek), nebo právě překročení (gnósis, theória, mluvení, myšlení). Merleau-Pontyho výklady v přednáškách z r. 1953 tak podle mého názoru přesvědčivě ukazují, že prohloubená analýza vnímání, nakolik je vyjadřováním, nás přibližuje k chápání toho, jak můžeme vnímaný svět reorganizovat pomocí symbolických prostředků, aniž bychom předpokládali inteligibilní universum o sobě, které by pouze shora udílelo svůj hotový rozumný řád „mnohoznačnému“ světu tělesné existence.

Viděli jsme také, že „transfiguraci“, ke které by mělo docházet při přechodu mezi vnímáním a myšlením, můžeme podle Merleau-Pontyho chápat jedině na základě radikálně nového pojetí těla. Jakožto tělesné schéma není tělo ani předmětem, ani souborem vjemů, je v silném smyslu naším hlediskem vůči světu. Člení se korelativně k činnosti a v jejím průběhu, tj. nemá nějakou předem fixovanou strukturu, která by a priori determinovala význam, ani však není z hlediska existence významu ve zkušenosti něčím nepodstatným či pouze omezujícím. Tělo je tak instancí, která nejenom otevírá a průběžně nese, ale zejména také umožňuje vést dál proces diferenciace systému vzájemného odkazování mého postoje vůči světu a jevení ve světě. To, co je ve vyjadřování ve vlastním smyslu novým způsobem ,převzato“ a sublimováno, je právě tělo ve smyslu implicitní výchozí normy každé dílčí zkušenosti, tj. perspektiva vyjadřovaná v každém jevu, vůči němuž je perspektivou. Tělo nám otevírá svět, je perspektivou každého vnímání a výchozí pozicí každé tělesné činnosti, avšak na úrovni vnímání světa jako „prrírodní“ krajiny, tj. ne-symbolických daností a reaktivního postoje, tělo nevyčerpává možnosti zaujímat perspektivy a konat. Vyjadřovací akt užívá tělo novým způsobem, čímž „posouvá normy“"52 etablované na rovině těla jakožto vnímajícího. Gesto již není pouze interakcí s vnímatelným světem, nýbrž právě aktivitou, tj. používá něco z vnímaného světa k účelům, které

52 M. Merleau-Ponty, Husserl et la notion de Nature, in: týž, Parcours deux, str. 223. 
překračují prosté vnímání v určité situaci. Vyjadřovací symbolické akty tedy stále fungují na principu perspektiva-jev (tj. tělo na pozadí - figura jevu), avšak detailněji člení, dourčuji tento vztah pomocí gestických či na symbolech založených výkonů, kulturních diferenciačních systémů. Udávají tak novou normu, vůči níž vystupují jevy, otevírají zkušenostní perspektivu, která překračuje možnosti těla a jeho norem, postojů, perspektiv a činností.

Když tak bude nakonec Merleau-Ponty tvrdit, že „duch čili myšlení“ je „,sublimací tělesnosti“" 53 je zřejmé, že nejde jen o metaforický způsob vyjadřování, ani o dogmatickou tezi. Promluva, řečový akt formuje celek vyslovitelného, tak jako postoj a pohyb mého těla formuje krajinu vnímatelného - je zaujetím perspektivy, vymezením postavení. Tak jako je mé tělo „opěrným bodem“ mého tělesně-perceptivního života, ${ }^{54}$ „mé myšlení by nemohlo ani o krok postoupit, pokud by se jím otevřený horizont smyslu neproměňoval pomocí řeči v něco, čemu se na divadle říká praktikábl“. ${ }^{55}$ Tělesnost, jež zde má být myšlením sublimována, tak samozřejmě není tělo jakožto předmět, „kus z masa a kostí“, nýbrž tělo jako sídlo a „zprostředkovatel“ vzájemného vyjadřování vnímatelného a vnímání, jejich „reversibility“, jak později řekne Merleau-Ponty. ${ }^{56}$ Dostáváme tak jasnou fenomenologickou odpověd' na otázku, v jakém smyslu je tělo „nutné $k$ myšleni". Myšlení není sublimací těla jako předmětu, je sublimací této reversibility ${ }^{57}$ či cirkularity perspektiva-jev, jejímž „prototypem“ je vnímající tělo a již diferenciační kulturní systémy dourčují, tj. také předpokládají.

Merleau-Pontyho pojmové uchopení problému „překročení“ vnímání tak nevystihuje pouze ,,analogii“" mezi vztahy tělo-vjem a promluva-myšlenka, nýbrž také jejich asymetrii, což znamená relativní samostatnost či odlišnost řeči a myšlení a zároveň fakt, že jsou fundovány tělesně perceptivním životem. Tělo je „nositelem“ diakritického systému vnímání-vnímané, jejž je možno hlouběji kulturně strukturovat (,,sublimace“),

53 M. Merleau-Ponty, Viditelné a neviditelné, přel. M. Petřríček, Praha 1998, str. 150; upravuji český překlad, Merleau-Ponty zde mluví o chair, což má zásadní význam, viz pozn. 56.

54 M. Merleau-Ponty, L'homme et l'adversité, in: týž, Signes, str. 373.

55 M. Merleau-Ponty, Předmluva ke Znakům, in: týž, Smysl filosofického tázání. Dva texty k Viditelnému a neviditelnému, přel. J. Halák, Praha 2016, str. 18.

56 Pojem tělesnosti (chair) je u Merleau-Pontyho definován právě jako reversibilita vnímání a vnímaného, srv. M. Merleau-Ponty, Viditelné a neviditelné, např. str. 143.

57 Tamt., str. 150: „fenomén reversibility... nese mluvu“, stejně jako vnímání. 
a překročit tak horizont vnímatelného, přičemž jedna ze struktur tohoto dourčení (ř č) je s to „sedimentovat“, tj. získávat „relativní samostatnost“ vůči svému původnímu nositeli. Sedimentace řeči, resp. gnósis, jež řeč předpokládá, je však Merleau-Pontym v přednáškách o vyjadřování pouze oznámena, nikoli vyložena, čímž také zůstává otevřená otázka „oddělitelnosti“ významů od diakritických systémů, díky nimž si je osvojujeme (otázka idealit). Výklad tohoto problému by si vyžádal věnovat se Merleau-Pontyho tematickým úvahám o řeči.

Ve světle těchto úvah stojí za povšimnutí konečně i to, že pojem vyjadřování systematizuje vybrané aspekty popisů z Fenomenologie vnímání a vede již naši pozornost určitým směrem, jenž se ukáže jako rozhodující pro další fázi Merleau-Pontyho vývoje. V r. 1953 již nejde pouze o to myslet vnímání jinak než jako intelektuální uchopování předmětu, nýbrž zcela zbavit pojem vědomí jeho role svého druhu garanta struktury zkušenosti. Perspektiva vzájemného vyjadřování tělo-jev již realizuje určitou „decentraci“ našeho pohledu na zkušenost, čímž shrnuje celou řadu zjištění, podle nichž se svět nerozkládá pouze před pohledem subjektu, jako korelát jeho intencionálního zaměření, nýbrž jej obklopuje, prostupuje, mobilizuje či zatěžuje. Jestliže tento princip nefunguje pouze na rovině vnímání, ale i dále $\mathrm{v}$ „myšlení“, představuje pozitivní alternativu vůči objektivistickým a subjektivistickým teoriím zkušenosti a má podle všeho skutečně ontologické důsledky, protože neponechává místo pro žádný subjekt, jehož podstatou by bylo myšlení. Zcela „decentrované“ formulace z pozdního období Merleau-Pontyho filosofie, jež vyjadřují tuto změnu ontologie, by nyní měly být o něco pochopitelnější: jakožto „sídlo“ vzájemného vyjadřování perspektivy a jevu je „subjekt" zkušenosti „překřrižení“, „záhyb“, „chiasma“, „zavíjení do sebe“ viditelnosti ${ }^{58}$ - ono „X, kde Bytí přichází k sobě, žije samo pro sebe nebo opět pro sebe ožívá" “ ${ }^{59}$ Jedním z přínosů přednášek o vyjadřování tedy také je, že ukazují, jak o řád obecnější formulace z období Viditelného a neviditelného vyrůstají z velmi konkrétních a mnohdy až technických znalostí z celé řady oblastí empirického zkoumání, že tedy nemají tak spekulativní charakter, jak by se mohlo zdát bez znalosti souvislostí. ${ }^{60}$

58 Tyto formulace se opakovaně vyskytují ve Viditelném a neviditelném.

59 M. Merleau-Ponty, Koncept k Viditelnému a neviditelnému, in: týž, Smysl filosofického tázání. Dva texty k Viditelnému a neviditelnému, str. 38. Srv. již Fenomenologie vnimání, str. 268.

60 Tato studie je výsledkem badatelské činnosti podporované Grantovou agenturou České republiky v rámci grantu GA ČR 16-17984Y „Kořeny Merleau-Ponty- 
Au moment où il entre au Collège de France, Merleau-Ponty considère comme la tâche la plus importante une nouvelle analyse de la rationalité qui éclaircirait son attache à la vie perceptive-corporelle. Les activités expressives humaines, dont la forme la plus élaborée est la formulation de la pensée en langage, sont une reprise explicite de ce qu'on trouve déjà au niveau de la perception comme la référence implicite et mutuelle entre le sujet percevant et la réalité perçue. Dans notre article, nous tentons de reconstituer l'argumentation de Merleau-Ponty à partir des notes qu'il a rédigées en vue de son cours, et nous présentons une interprétation des concept-clés « expression » et « schéma corporel ».

SUMMARY

In his initial lecture course at the Collège de France, Merleau-Ponty attempted to develop a new analysis of rational thought in order to clarify its link with corporeal-perceptive life. The formulation of thought in language as the most elaborate human activity of expression explicitly takes over what we already observe in perception as the implicit and mutual reference between the perceiving subject and that which is perceived. The article reconstructs Merleau-Ponty's argumentat, based on his preparatory notes for the lectures, and provides an interpretation of the key concepts of "expression" and "body schema".

ho převrácení objektivistického paradigmatu v přednáškách z Collège de France“ řešeného na Univerzitě Palackého v Olomouci. 